\title{
Absorption of lysine and methionine from the proximal colon of the piglet
}

\author{
BY ALISON J. DARRAGH ${ }^{1}$, PETER D. CRANWELL ${ }^{2}$ AND PAUL J. MOUGHAN ${ }^{1}$ \\ ${ }^{1}$ Department of Animal Science, Massey University, Palmerston North, New Zealand \\ ${ }^{2}$ School of Agriculture, La Trobe University, Bundoora, Victoria 3083, Australia
}

(Received 22 January 1993 - Revised 2 August 1993 - Accepted 14 September 1993)

\begin{abstract}
The present study aimed to determine whether lysine and/or methionine are absorbed in nutritionally significant amounts from the proximal colon of milk-formula-fed piglets (15-32 d old; $2.0-7.4 \mathrm{~kg}$ liveweight). Piglets, surgically prepared with simple catheters which allowed infusion into the proximal colon, were randomly allocated to one of two milk-formula diets which were either $40 \%$ deficient in lysine $(\mathrm{L}-$ diet) or $60 \%$ deficient in methionine and $40 \%$ deficient in cysteine $(\mathrm{S}$ - diet), yet balanced for all other amino acids. The piglets were individually bottle-fed the milk-formula diets seven times daily at $2 \mathrm{~h}$ intervals between 08.00 and 20.00 hours. Physiological saline $(9 \mathrm{~g} \mathrm{NaCl} / \mathrm{l})$ or an isotonic solution containing the deficient amino acid was infused via the catheter at each feeding. The experimental procedure followed a cross-over design. Total daily excretions of urinary urea and total $\mathbf{N}$ were determined. There were no significant differences $(P>0.05)$ in urinary $\mathrm{N}$ metabolite excretion for piglets infused with amino acids compared with those infused with saline. Lysine and methionine do not appear to be absorbed in nutritionally significant amounts from the proximal colon of the milk-fed piglet.
\end{abstract}

Piglet: Amino acids: Absorption: Proximal colon

Determination of amino acid digestibility at the terminal ileum of the pig is generally considered to be more accurate than the traditional faecal method (Low, 1980; Moughan \& Smith, 1982; Sauer \& Ozimek, 1986). Differences between faecal and ileal amino acid digestibilities have been found with growing pigs (Zebrowska, 1978; Jorgensen \& Sauer, 1982) and milk-fed piglets (Moughan et al. 1990). The ileal method, while apparently superior to the faecal digestibility technique, relies on the assumption that amino acids are not absorbed in nutritionally significant amounts from the large intestine. $\mathrm{N}$ absorbed from the large intestine is thought to be in the form of ammonia together with small amounts of amines and amides, which are ultimately excreted mainly as urinary urea (Hoover \& Heitmann, 1975; Zebrowska, 1982; Just, 1983; McNeil, 1988).

Whereas several studies have shown that amino acids are not absorbed in significant amounts from the large intestine of growing pigs (Zebrowska, 1973, 1975, 1978; Just et al. 1981; Schmitz et al. 1991), there is some evidence for amino acid absorption from the large intestine of the piglet during the first week after birth. James \& Smith (1976) found that at birth the piglet proximal colon has a structure similar to that of the small intestine and speculated that absorption of amino acids in the hindgut of young animals may be of physiological importance. Furthermore, results of several in vitro studies have shown that methionine is absorbed into the proximal colonic epithelium of new-born piglets (James \& Smith, 1976; Smith \& James, 1976; Jarvis et al. 1977). While there are no published quantitative data on the in vivo absorption of amino acids in neonatal piglets, Heine et al. (1987) demonstrated absorption and retention of protein $\mathrm{N}$ in the colon of human infants. 
Table 1. Composition of the milk-formula diets ( $\mathrm{g} / \mathrm{kg}$ oven-dry weight)

\begin{tabular}{|c|c|c|c|}
\hline & \multicolumn{3}{|c|}{ Milk-formula diets } \\
\hline & Preliminary & $\mathrm{L}-$ & $\mathrm{S}-$ \\
\hline Skimmed milk & $165 \cdot 45$ & $160 \cdot 94$ & $149 \cdot 27$ \\
\hline Demineralized whey powder & $277 \cdot 15$ & $269 \cdot 60$ & $250 \cdot 05$ \\
\hline Lactose & 263.00 & $255 \cdot 84$ & 237.28 \\
\hline Palm oil & $92 \cdot 40$ & $89 \cdot 89$ & $83 \cdot 36$ \\
\hline Coconut oil & $92 \cdot 40$ & $89 \cdot 89$ & $83 \cdot 36$ \\
\hline Soya-bean oil & $92 \cdot 40$ & $89 \cdot 89$ & $83 \cdot 36$ \\
\hline Minerals and vitamins* & $17 \cdot 20$ & 16.73 & $15 \cdot 52$ \\
\hline \multicolumn{4}{|l|}{ Synthetic amino acids $\dagger$} \\
\hline Lysine $\mathrm{HCl}$ & - & - & $17 \cdot 70$ \\
\hline Methionine & 一 & $0 \cdot 87$ & - \\
\hline Cysteine & - & $2 \cdot 17$ & $2 \cdot 35$ \\
\hline Threonine & - & 1.65 & $8 \cdot 18$ \\
\hline Tryptophan & - & 0.90 & $2 \cdot 95$ \\
\hline Isoleucine & 一 & $2 \cdot 07$ & 8.43 \\
\hline Leucine & - & $5 \cdot 16$ & 18.48 \\
\hline Histidine & - & $2 \cdot 93$ & $7 \cdot 12$ \\
\hline Phenylalanine & - & 2.98 & 9.02 \\
\hline Tyrosine & - & $4 \cdot 70$ & $11-55$ \\
\hline Valine & - & $3 \cdot 78$ & $12 \cdot 00$ \\
\hline
\end{tabular}

$\mathrm{L}$-, milk-formula diet, $40 \%$ deficient in lysine; $\mathrm{S}-$, milk-formula diet, $60 \%$ deficient in methionine and $40 \%$ deficient in cysteine.

* The mineral and vitamin content of preliminary diet $(\mathrm{mg} / \mathrm{kg}$ oven-dry diet): Ca $3550, \mathrm{P} 2370, \mathrm{~K} 4740, \mathrm{Na}$ 1270, $\mathrm{Cl} 3220, \mathrm{Mg} \mathrm{384,} \mathrm{Fe} \mathrm{84,} \mathrm{Zn} \mathrm{43,} \mathrm{vitamin} \mathrm{E} \mathrm{79,} \mathrm{ascorbic} \mathrm{acid} \mathrm{468,} \mathrm{nicotinic} \mathrm{acid} \mathrm{84,} \mathrm{pantothenic} \mathrm{acid} 18$, choline $846 ; \mu \mathrm{g} / \mathrm{kg}$ oven-dry diet: $\mathrm{Mn} 130, \mathrm{Cu} 395, \mathrm{I} 51 \cdot 0$, vitamin $\mathrm{K} 45 \cdot 1$, thiamin 564 , riboflavin 846 , pyridoxine 355 , cyanocobalamin $1 \cdot 1$, retinol 508 , cholecalciferol $8 \cdot 4$, pteroylmonoglutamic acid $42 \cdot 3$, biotin $12 \cdot 4$.

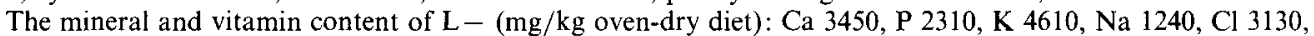
$\mathrm{Mg} 374, \mathrm{Fe} \mathrm{82,} \mathrm{Zn} \mathrm{42,} \mathrm{vitamin} \mathrm{E} \mathrm{77,} \mathrm{ascorbic} \mathrm{acid} \mathrm{455,} \mathrm{nicotinic} \mathrm{acid} \mathrm{82,} \mathrm{pantothenic} \mathrm{acid} \mathrm{18,} \mathrm{choline} 823 . \mu \mathrm{g} / \mathrm{kg}$ oven-dry diet: $\mathrm{Mn} 127, \mathrm{Cu} 384$, I 49.6 , vitamin $\mathrm{K} 43.9$, thiamin 549 , riboflavin 823 , pyridoxine 345 , cyanocobalamin $1 \cdot 1$, retinol 494 , cholecalciferol $8 \cdot 2$, pteroylmonoglutamic acid $41 \cdot 1$, biotin $12 \cdot 1$.

The mineral and vitamin content of $\mathrm{S}-(\mathrm{mg} / \mathrm{kg}$ oven-dry diet): $\mathrm{Ca} 3200, \mathrm{P} 2140, \mathrm{~K} \mathrm{4280,} \mathrm{Na} \mathrm{1150,} \mathrm{Cl} \mathrm{2910,}$ $\mathrm{Mg} 346, \mathrm{Fe} 76, \mathrm{Zn} 39$, vitamin E 71, ascorbic acid 422, nicotinic acid 76, pantothenic acid 16 , choline $763 . \mu \mathrm{g} / \mathrm{kg}$ oven-dry diet: $\mathrm{Mn} 117, \mathrm{Cu} 356$, I 460 , vitamin $\mathrm{K} 40 \cdot 7$, thiamin 509 , riboflavin 763 , pyridoxine 320 , cyanocobalamin $1 \cdot 0$, retinol 458 , cholecalciferol 7.6 , pteroylmonoglutamic acid 38.2 , biotin 11.2 .

$\dagger$ All synthetic amino acids were L-isomers.

The present study aimed to determine whether the dietary essential amino acids, lysine and methionine, are absorbed from the proximal colon of the milk-formula-fed piglet. The study examined the effect, on urinary $\mathrm{N}$ metabolite excretion, of infusions of free lysine or methionine into the proximal colon of piglets fed with liquid milk-formula diets which were either $40 \%$ deficient in lysine or $50 \%$ deficient in the sulphur amino acids.

\section{EXPERIMEN TAL}

All aspects of this study were approved by the Massey University Animal Ethics Committee.

\section{Animals and housing}

Twenty-one 6-d-old entire male Landrace $\times$ Large White piglets were selected at random from six litters at the Pig Research Unit, Massey University. Sixteen piglets were randomly chosen for the implantation of colonic catheters and five piglets remained unoperated. The 
Table 2. Nutrient composition of the experimental milk-formula diets ( $\mathrm{g} / \mathrm{kg}$ oven-dry diet $) \dagger$

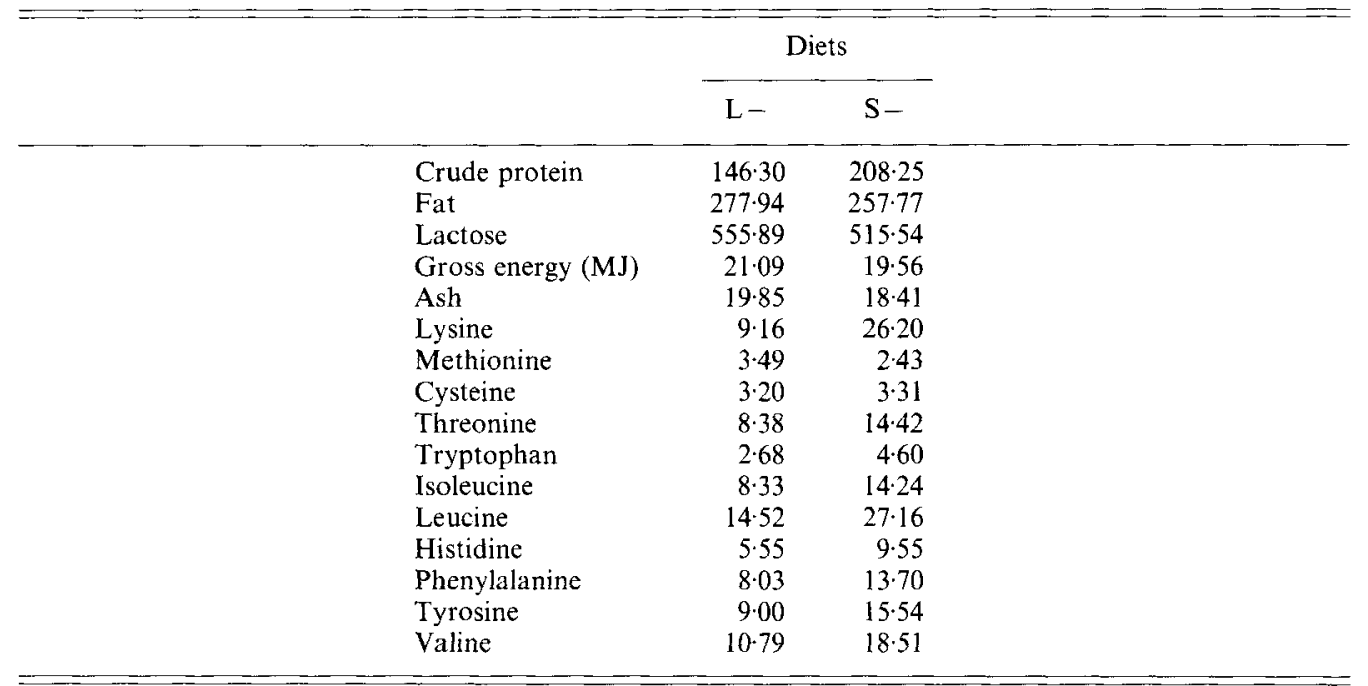

$\mathrm{L}$-, milk-formula diet, $40 \%$ deficient in lysine; $\mathrm{S}-$, milk-formula diet, $60 \%$ deficient in methionine and $40 \%$ deficient in cysteine.

$\uparrow$ Based on tabulated values.

Table 3. Dietary essential amino acid intakes $(\mathrm{g} / \mathrm{d})$ of $4 \mathrm{~kg}$ piglets given either the $L-$ or $\mathrm{S}-$ diets, compared with recommended (Agricultural Research Council, 1981) amino acid intakes for the milk-fed piglet

\begin{tabular}{|c|c|c|c|}
\hline & \multicolumn{3}{|c|}{ Amino acid intake } \\
\hline & $\mathbf{L}-$ & $S-$ & Recommended* \\
\hline Lysine & 1.81 & 3.02 & 3.02 \\
\hline Methionine and cysteine & $1 \cdot 32$ & 0.66 & $1 \cdot 32$ \\
\hline Threonine & $1 \cdot 66$ & 1.66 & 1.66 \\
\hline Tryptophan & $0 \cdot 53$ & 0.53 & 0.53 \\
\hline Isoleucine & 1.64 & $1 \cdot 64$ & 1.64 \\
\hline Leucine & $3 \cdot 42$ & $3 \cdot 42$ & 3.42 \\
\hline Histidine & $1 \cdot 10$ & $1 \cdot 10$ & $1 \cdot 10$ \\
\hline Phenylalanine and tyrosine & $3 \cdot 37$ & $3 \cdot 37$ & $3 \cdot 37$ \\
\hline Valine & $2 \cdot 14$ & $2 \cdot 14$ & $2 \cdot 14$ \\
\hline
\end{tabular}

$\mathrm{L}-$, milk-formula diet, $40 \%$ deficient in lysine given to piglets at a rate of $240 \mathrm{~g}$ liquid-milk-formula diet $/ \mathrm{kg}$ liveweight ; $\mathrm{S}-$, milk-formula diet, $60 \%$ deficient in methionine and $40 \%$ deficient in cysteine given to piglets at a rate of $130 \mathrm{~g}$ liquid-milk-formula diet $/ \mathrm{kg}$ liveweight.

* Recommended levels calculated based on the amino acid composition of mature sow's milk, and the expected intake of sow's milk by a $4 \mathrm{~kg}$ suckled piglet (Agricultural Research Council, 1981). 
piglets were individually and randomly penned in moulded-plastic metabolism cages which were designed to allow complete collection of urine. The animals were kept in a temperature-controlled room maintained at $30 \pm 1^{\circ}$.

\section{Surgical preparation}

Anaesthesia was induced and maintained throughout surgery with halothane (Fluothane; Imperial Chemical Industries Ltd) which was inhaled through a mask, using concentrations of $5 \%$ in $\mathrm{O}_{2}$ for induction and $2-3 \%$ in $\mathrm{O}_{2}$ for maintenance. Each piglet was placed in left lateral recumbency and a $30-40 \mathrm{~mm}$ dorsal-ventral incision was made in the flank midway between the last rib and the pelvis. The caecum was located and exteriorized; a purse-string suture was inserted in the caecal wall as close as possible to the ileo-caecal junction. The catheter was inserted via an incision made through the wall of the caecum within the area of the purse-string suture. The catheter, which consisted of a $300 \mathrm{~mm}$ length of silastic medical-grade tubing ( $3.2 \mathrm{~mm}$ OD, $1.6 \mathrm{~mm}$ ID, dead space volume $1 \mathrm{ml}$; Dow Corning Corporation, Midland, MI, USA), had two silastic cuffs placed $3 \mathrm{~mm}$ apart, secured $50 \mathrm{~mm}$ from one end of the tubing with silastic, medical-grade adhesive (Dow Corning Corporation). After the catheter was inserted into the caecum the cuffs were positioned on either side of the caecal wall and the purse-string suture tied securely around the catheter between the two cuffs. The tip of the catheter was positioned in the proximal large intestine so that it was distal to the ileo-caecal junction. A second purse-string suture was inserted to secure the catheter which was subsequently laid along, and sutured to, the external caecal wall. The external tip of the catheter was sealed with a metal pin. Using a specially designed trocar and cannula the catheter was tunnelled through the peritoneum and muscle layers, and then subcutaneously to the dorsum of the piglet where it was externalized in the midlumbar region. A towelling pouch with a Velcro seal was attached to the dorsum of the piglet with elasticized adhesive tape. The $200 \mathrm{~mm}$ of exposed catheter was coiled and placed within the pouch. Surgical netting (Systenet; International Surgical Netting, Zurich, Switzerland) was placed over the body of the piglet to protect the pouch.

While under anaesthesia, each piglet was shaved around the anal and tail region, and karaya base plates (Combihesive C321; E. R. Squibb \& Sons Limited, Auckland, New Zealand) designed for the attachment of human ostomy bags were affixed to the skin with elasticized adhesive tape so that the $32 \mathrm{~mm}$ opening in each plate was directly over the anus. A $100 \times 100 \mathrm{~mm}$ plastic bag (Combihesive C329; E. R. Squibb \& Sons Limited) was attached to the base plate. The five unoperated piglets, which were used to examine the possible effects of surgery on urinary $\mathrm{N}$ metabolite excretion, were also fitted with karaya base plates. By using the ostomy bag technique it was possible to ensure complete and separate collection of faeces from the piglets. The ostomy bags also prevented the practice of coprophagy.

\section{Diets}

The ingredient and nutrient compositions of the milk-formula diets used during the preliminary period (preliminary diet) and the experimental periods ( $\mathrm{L}-$ diet and $\mathrm{S}-$ diet) are given in Tables 1 and 2. The diets used during the experimental periods were formulated to meet the amino acid requirements of piglets for growth except for either lysine $\left(\mathrm{L}_{-}\right)$) or the sulphur amino acids $(\mathbf{S}-)$. The amino acid requirement was based on the composition of sow's milk at peak lactation (Agricultural Research Council, 1981). The diet deficient in lysine ( $\mathrm{L}-$ diet) contained $60 \%$ of the required level of lysine, and the diet deficient in the sulphur amino acids ( $\mathrm{S}-$ diet) contained $60 \%$ and $40 \%$ of the required levels of cysteine and methionine respectively, giving a diet that was $50 \%$ deficient in total sulphur amino 
Table 4. The design of the experiment

\begin{tabular}{|c|c|c|c|c|c|c|c|}
\hline \multirow{2}{*}{$\begin{array}{l}\text { Time period ... } \\
\text { Age (d)... } \\
\text { Diet and treatment ... } \\
\text { Pigs: }\end{array}$} & \multirow[b]{2}{*}{$n$} & \multicolumn{2}{|c|}{$\stackrel{1}{1}$} & \multicolumn{2}{|c|}{$\stackrel{2}{21-26}$} & \multicolumn{2}{|c|}{$\begin{array}{c}3 \\
27-32\end{array}$} \\
\hline & & Diet & Infusion & Diet & Infusion & Diet & Infusion \\
\hline Catheterized* & 4 & L- & Saline & $\mathrm{L}-$ & Lysine & $\mathrm{L}+$ & Saline \\
\hline Catheterized & 4 & L- & Lysine & $\mathrm{L}-$ & Saline & $\mathrm{L}+$ & Saline \\
\hline Catheterized & 4 & $S-$ & Saline & $S_{-}$ & Methionine & $s+$ & Saline \\
\hline Catheterized & 4 & $S_{-}$ & Methionine & $S-$ & Saline & $S+$ & Saline \\
\hline Unoperated & 5 & $S-$ & $-\dagger$ & $\mathrm{S}-$ & - & $\mathrm{S}-$ & - \\
\hline
\end{tabular}

$\mathrm{L}-$, milk-formula diet, $40 \%$ deficient in lysine; $\mathrm{S}-$, milk-formula diet, $60 \%$ deficient in methionine and $40 \%$ deficient in cysteine; saline, $9 \mathrm{~g} \mathrm{NaCl} / 1$.

* Two piglets in this group did not complete the experiment because their catheters became dislodged during time-period 1 .

$\dagger$ Unoperated pigs were not infused.

$¥$ For details of animals and procedures, see pp. 740-744.

acids. The estimated amino acid intakes of piglets fed either the $\mathrm{L}-$ or $\mathrm{S}-$ diets are compared with recommended daily amino acid intakes in Table 3.

During the last period of the experiment the diets fed to the catheterized piglets were modified ( $6.24 \mathrm{~g}$ lysine as lysine monohydrochloride $/ \mathrm{kg}$ dry matter was added to the $\mathrm{L}-$ diet, and $3.93 \mathrm{~g}$ methionine $/ \mathrm{kg}$ dry matter was added to the $\mathrm{S}-$ diet) to be balanced for lysine $(\mathrm{L}+$ diet) and methionine $(\mathrm{S}+$ diet $)$.

The dry milk-formula diets were mixed with water ( $200 \mathrm{~g}$ dry matter/ $\mathrm{kg}$ liquid formula) daily and kept refrigerated at $4^{\circ}$. The liquid milk-formula diets were warmed to $35^{\circ}$ before feeding.

\section{Experimental procedure}

In the $10 \mathrm{~d}$ following removal from the sow and before the commencement of the experimental period the piglets (average age $15 \mathrm{~d}$, mean body weight 2.85 (SE 0.140$) \mathrm{kg}$ ) were trained to drink the preliminary diet from bottles with soft rubber teats attached. Surgery was performed when the piglets were $10-11 \mathrm{~d}$ old, $4-5 \mathrm{~d}$ before the commencement of the experimental period. The piglets recovered rapidly from surgery and were given their daily allowances of milk-formula in equal amounts at $2 \mathrm{~h}$ intervals from 08.00 to 20.00 hours, i.e. seven feedings/d.

The sixteen catheterized piglets were allocated at random to either the $\mathrm{L}-$ diet or the $\mathrm{S}-$ diet (eight piglets/diet) and the five unoperated piglets were allocated to the $S-\operatorname{diet}$ (Table 4). The piglets received their respective milk-formula diets for two consecutive $6 \mathrm{~d}$ experimental periods (time-period 1 and time-period 2).

The piglets were weighed accurately (to within $10 \mathrm{~g}$ ) at the beginning of each time period and were given the respective diets at set levels of intake $(240 \mathrm{~g}$ and $130 \mathrm{~g}$ liquid milkformula diet $/ \mathrm{kg}$ liveweight per $\mathrm{d}$ for the $\mathrm{L}-$ and $\mathrm{S}$ - diets respectively) to give the planned levels of amino acid deficiency. During a final $6 \mathrm{~d}$ period (time-period 3 ) the catheterized piglets which had previously received the $\mathrm{L}$ - diet were fed on a diet supplemented with synthetic lysine monohydrochloride $(\mathrm{L}+$ diet), and piglets that had received the $\mathrm{S}-$ diet were fed on a diet supplemented with methionine $(S+$ diet $)$. The five unoperated piglets received the $\mathrm{S}$ - diet during all three time periods.

During time-period 1 , four randomly selected catheterized piglets on each diet received 
infusions of the deficient amino acid into the proximal large intestine, while the other four piglets received infusions of physiological saline $(9 \mathrm{~g} \mathrm{NaCl} / 1)$. In time-period 2 the infusion regime was reversed. The amounts of amino acid infused were $60.2 \mathrm{mg}$ lysine $/ \mathrm{kg}$ liveweight per $\mathrm{d}(13.3 \%$ lysine fed $/ \mathrm{kg}$ liveweight per $\mathrm{d})$ and $20.4 \mathrm{mg}$ methionine $/ \mathrm{kg}$ liveweight per $\mathrm{d}$ $(12.4 \%$ methionine fed $/ \mathrm{kg}$ liveweight per $\mathrm{d})$ for piglets given the $\mathrm{L}-$ - and $\mathrm{S}-$ diets respectively. These amounts were based on the assumption that $80 \%$ of amino acids in a milk-formula diet would be completely absorbed by the terminal ileum. Thus the amounts of amino acid infused into the proximal colon approximated the levels of these amino acids expected to be flowing into the hindgut of normal, suckled piglets. The total amount of each synthetic amino acid to be infused into each piglet daily was dissolved in $10 \mathrm{ml}$ distilled water to which $\mathrm{NaCl}$ was added to provide a $300 \mathrm{~mm}$ isotonic solution. The daily infusate was divided into seven equal portions with each portion being warmed to $37^{\circ}$ and infused at each of the seven feedings. All amino acid infusions were followed by a $1 \mathrm{ml}$ infusion of physiological saline $(9 \mathrm{~g} \mathrm{NaCl} / 1)$ to fill the dead-space of the catheter. The catheterized piglets not receiving an amino acid infusion during each time-period, were infused with $2 \mathrm{ml}$ physiological saline during each feeding. In time-period 3 , all catheterized piglets received $2 \mathrm{ml}$ infusions of physiological saline at each feeding.

During the final $3 \mathrm{~d}$ of each $6 \mathrm{~d}$ time-period the urinary output of each piglet was collected three times daily $(08.00,12.00$ and 18.00 hours). The $3 \mathrm{~d}$ adaptation between each collection period was considered to be sufficient (Brown \& Cline, 1972a, $b$ ). The plastic metabolism cages were designed to ensure rapid collection of filtered urine into narrownecked plastic bottles containing $1.8 \mathrm{M}_{-} \mathrm{H}_{2} \mathrm{SO}_{4}(25 \mathrm{ml}$ acid/1 urine collected). The procedure for collection of urine included spraying the cage floor and sides three times daily with distilled water to minimize the loss of urinary N. Representative subsamples of the daily urine outputs were frozen. At the end of each time-period the daily urine outputs for each piglet over the $3 \mathrm{~d}$ collection period were bulked, subsampled and stored at $-20^{\circ}$. The ostomy bags remained intact during the trial, and faeces were collected daily from the ostomy bags and discarded.

At the completion of the $18 \mathrm{~d}$ experimental period the eight piglets that had been given the $\mathrm{S}+$ diet had free homoarginine (HA; L-homoarginine; Sigma Chemical Company) infused into the colon. HA is a synthetic analogue of lysine that does not occur naturally in the pig's digestive tract. The HA infusions $(8.6 \mathrm{mg} / \mathrm{kg}$ liveweight per infusion) were given $1 \mathrm{~h}$ before (11.00 hours) and at the 12.00 hours feeding. The piglets were killed with an overdose of sodium pentobarbitone (Pentobarb, $300 \mathrm{mg} / \mathrm{ml}$; South Island Chemicals Ltd, Christchurch, New Zealand) administered by intraperitoneal injection 30 min after the second infusion of HA. The body cavity was opened and the ileo-caecal junction immediately located and clamped. For each piglet the digesta from the final $200 \mathrm{~mm}$ ileum were flushed out with distilled water, collected and frozen for determination of HA to monitor possible backflow of digesta into the small intestine. At death the status and position of the catheter in the large intestine were noted.

\section{Analytical methods}

Urine was subjected to chemical determination in duplicate for total $\mathrm{N}$, urea and creatinine. Total $\mathrm{N}$ was determined by the Kjeldahl method (Association of Official Analytical Chemists, 1980) and urea and creatinine were determined colorimetrically on a Cobas Fara II autoanalyser (Hoffman-La Roche, Basel, Switzerland) using the methods of Tiffany et al. (1972) and Larsen (1972), respectively.

Standard samples of Analar grade ammonium ferrous sulphate, urea and creatinine were used to test the accuracy of the respective analyses. Recovery values for total N, urea and creatinine were $99.9 \%, 99.7 \%$ and $100 \%$ respectively. The precision (intra-assay variation) 
of the urea and creatinine assays was determined by including six standard samples per run of sixty test samples. The intra-assay coefficient of variation was $2.0 \%$ and $1.1 \%$ for urea and creatinine respectively. The overall mean differences between duplicates within samples (expressed as a proportion of the mean), were $2 \cdot 1 \%, 1 \cdot 5 \%$ and $1.0 \%$ for total $\mathrm{N}$, urea and creatinine respectively.

Urinary $\mathrm{N}$ metabolite excretions were calculated on the basis that urea contains $46.7 \% \mathrm{~N}$ and creatinine $37.2 \% \mathrm{~N}$, on a molecular weight basis, and the daily excretions were expressed per unit of metabolic body weight $\left(\mathrm{kg}^{0.75}\right)$. Freeze-dried ileal digesta samples $(7 \mathrm{mg})$ were acid-hydrolysed in $0.5 \mathrm{ml} 6 \mathrm{M}-\mathrm{HCl}\left(+0.1 \%\right.$ phenol) for $24 \mathrm{~h}$ at $110 \pm 2^{\circ}$, and prepared for determination of $\mathrm{HA}$ on a Pharmacia LKB-Alpha plus amino acid autoanalyser (Cambridge, England).

\section{Statistical analysis}

Treatment means were compared using a simple one-way analysis of variance. A paired $t$ test was used to compare urinary $\mathrm{N}$ metabolite excretion rates for piglets given either the $\mathrm{L}$ - or $\mathrm{S}$ - diets in time-period 2 , with the urinary metabolite excretion rates for the same piglets given the $\mathrm{L}+$ or $\mathrm{S}+$ diets respectively, during time-period 3 .

\section{RESULTS}

Two piglets $(\mathrm{L}-$ diet) did not complete the experiment because their catheters became dislodged during time-period 1. All catheterized piglets resumed normal feed intakes within $12 \mathrm{~h}$ of surgery and, together with the unoperated piglets, appeared healthy and readily consumed their set daily intakes of milk-formula throughout the study. At the beginning of time-periods 1, 2 and 3 and at the end of time-period 3, average piglet liveweights (mean (SE)) were $2.85(0.140) \mathrm{kg}, 3.35(0.185) \mathrm{kg}, 3.93(0.484) \mathrm{kg}$ and $4.73(0.310) \mathrm{kg}$ respectively, with a range of $2 \cdot 0-7 \cdot 4 \mathrm{~kg}$ throughout the experiment.

HA could not be detected in any of the samples of ileal digesta from the catheterized piglets colonically infused with this synthetic amino acid. Thus, there did not appear to have been any backflow of infused amino acids into the small intestine. Post-mortem examination of all catheterized piglets showed that their catheters remained in place and that the tips of the catheters were all situated distal to the ileo-caecal junction.

The mean daily urinary $\mathrm{N}$ metabolite excretion rates in time period 2 were used to assess whether there was any effect of surgery per se. The differences in $\mathrm{N}$ metabolite excretions between the catheterized and unoperated piglets given the $\mathrm{S}-$ diet in time-period 2 (Fig. 1) were not significantly different $(P>0.05)$. Thus, surgical intervention and the establishment of chronic catheters in the large intestine did not appear to have any effect on $\mathrm{N}$ metabolism.

In all piglets there was no significant $(P>0 \cdot 05)$ effect of diet on daily urinary creatinine excretion either within or between time periods. The overall mean for individual piglet's mean daily excretion of urinary creatinine was 38.0 (SE 1.42 ) $\mathrm{mg} / \mathrm{kg}^{0.75}$ per $\mathrm{d}$ (range $29.0-49 \cdot 5 \mathrm{mg}$ creatinine $/ \mathrm{kg}^{0.75}$ per d). The overall mean for individual piglet's coefficient of variation for daily urinary creatinine excretion was $14.7 \%$ (range $9 \cdot 8-22 \cdot 1 \%$ ).

Comparison of urinary total $\mathrm{N}$ and urea- $\mathrm{N}$ excretion for piglets fed either the $\mathrm{L}-$ or $\mathrm{S}-$ diets and infused with physiological saline or amino acids during time-periods 1 and 2 showed a significant $(P<0.05)$ increase in excretion over time. As a result of this unexpected time effect, comparisons of urinary $\mathrm{N}$ metabolite excretion rates between piglets infused with either physiological saline or amino acids were restricted to within time periods (Tables 5 and 6). 


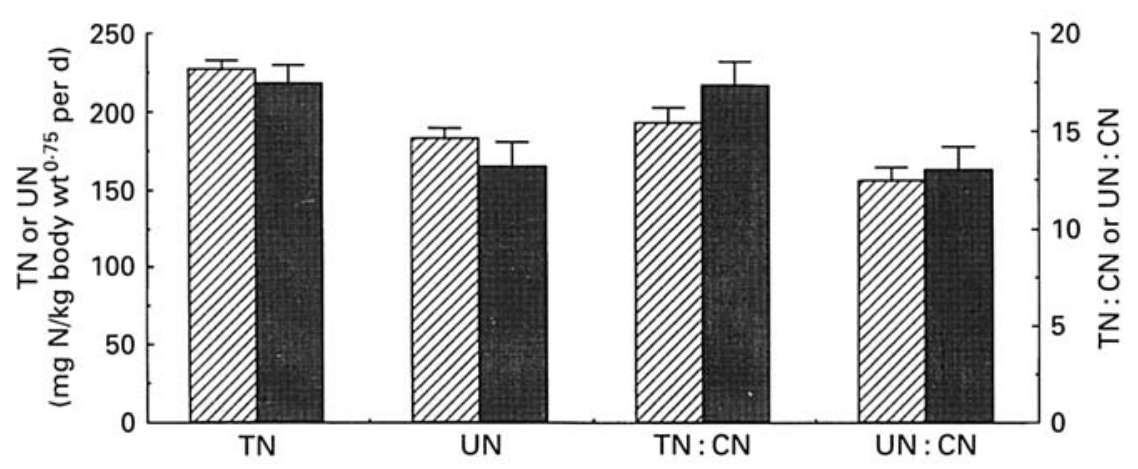

Fig. 1. Comparison of the mean daily urinary excretion of total $N(T N)$ and urea-N (UN), and the ratios between TN and the mean daily urinary creatinine-N (CN) excretion (TN:CN), and between $U N$ and $C N$ (UN:CN) in time-period 2 for catheterized $(\square ; n 8)$ and unoperated piglets $(\boldsymbol{D} ; n 5)$. All the piglets were fed on a milk-formula diet that was $60 \%$ deficient in methionine and $40 \%$ deficient in cysteine $(\mathrm{S}-$ diet). Values are means with their standard errors represented by vertical bars. Mean values for catheterized piglets were not significantly different from those for unoperated piglets: $P>0.05$.

Table 5. Mean daily urinary $N$ metabolite excretion rates $\left(\mathrm{mg} / \mathrm{kg}^{0.75}\right.$ per $\left.d\right)$ for piglets infused colonically with either physiological saline $(9 \mathrm{~g} \mathrm{NaCl} / \mathrm{l})$ or free lysine, while fed with a milkformula diet $40 \%$ deficient in lysine $(L-$ diet $) \dagger$

(Mean values with their standard errors for two to four piglets)

\begin{tabular}{|c|c|c|c|c|c|}
\hline & \multicolumn{4}{|c|}{ Infusion } & \multirow{3}{*}{$\begin{array}{c}\text { Statistical } \\
\text { significance }\end{array}$} \\
\hline & \multicolumn{2}{|c|}{ Saline } & \multicolumn{2}{|c|}{ Lysine } & \\
\hline & Mean & $\mathrm{SE}$ & Mean & $\mathrm{SE}$ & \\
\hline \multicolumn{6}{|l|}{ Time-period 17} \\
\hline Total N & $154 \cdot 3$ & $7 \cdot 86$ & $153 \cdot 5$ & 12.99 & NS \\
\hline Urea-N & 89.5 & $6 \cdot 47$ & $101 \cdot 8$ & $8 \cdot 29$ & NS \\
\hline Total $\mathbf{N}$ : creatinine- $\mathbf{N}$ & $10 \cdot 4$ & $1 \cdot 16$ & $11 \cdot 3$ & 0.21 & NS \\
\hline Urea-N : creatinine- $\mathrm{N}$ & $6 \cdot 0$ & 0.54 & $7 \cdot 5$ & $0 \cdot 20$ & $*$ \\
\hline \multicolumn{6}{|l|}{ Time-period $2+$} \\
\hline Total N & $202 \cdot 4$ & $13 \cdot 75$ & $209 \cdot 2$ & $28 \cdot 54$ & NS \\
\hline Urea-N & $142 \cdot 1$ & 11.98 & 158.0 & $5 \cdot 14$ & NS \\
\hline Total $N$ :creatinine $-N$ & 130 & 0.07 & $12 \cdot 5$ & $0 \cdot 21$ & $*$ \\
\hline Urea-N:creatinine- $\mathrm{N}$ & $9 \cdot 1$ & $0 \cdot 27$ & $9 \cdot 6$ & $0 \cdot 84$ & NS \\
\hline
\end{tabular}

* $P<0.05 ; \mathrm{NS}$, not significant.

$\dagger$ For details of diets and procedures, see Tables 1 and 4 and pp. 740-745.

$\$$ Time-period 1, saline, $n 2$, lysine, $n 4$; time-period 2, saline, $n 4$, lysine, $n 2$.

For piglets fed with the $\mathrm{L}$ - diet there were no significant differences $(P>0.05)$ in the excretion of urinary $\mathrm{N}$ metabolites between those infused with saline and those infused with lysine in either time-period 1 or time-period 2 (Table 5). In the piglets infused with lysine the urea- $\mathrm{N}$ : creatinine- $\mathrm{N}$ ratio in time-period 1 was significantly higher $(P<0.05)$, and the total $\mathrm{N}$ :creatinine- $\mathrm{N}$ ratio in time-period 2 was slightly but significantly lower $(P<0.05)$ than in piglets infused with saline.

For piglets fed on the $\mathrm{S}-$ diet there were no significant differences $(P>0.05)$ in the excretion of urinary $\mathrm{N}$ metabolites between those infused with saline or those infused with methionine in either time-period 1 or time-period 2 (Table 6). In time-period 3 the five 
Table 6. Mean daily urinary $N$ metabolite excretion rates $\left(\mathrm{mg} / \mathrm{kg}^{0.75}\right.$ per d) for piglets infused colonically with either physiological saline $(9 \mathrm{~g} \mathrm{NaCl} /)$ or free methionine, while fed with a milk-formula diet $60 \%$ deficient in methionine and $40 \%$ deficient in cysteine $(S-$ diet $) \dagger$

(Mean values with their standard errors for four piglets)

\begin{tabular}{|c|c|c|c|c|c|}
\hline & \multicolumn{4}{|c|}{ Infusion } & \multirow{3}{*}{$\begin{array}{c}\text { Statistical } \\
\text { significance }\end{array}$} \\
\hline & \multicolumn{2}{|c|}{ Saline } & \multicolumn{2}{|c|}{ Methionine } & \\
\hline & Mean & $\mathrm{SE}$ & Mean & $\mathrm{SE}$ & \\
\hline \multicolumn{6}{|l|}{ Time-period 1} \\
\hline Total N & $184 \cdot 9$ & $10 \cdot 42$ & $179 \cdot 8$ & $3 \cdot 72$ & NS \\
\hline Urea-N & $152 \cdot 8$ & $10 \cdot 20$ & $141 \cdot 6$ & $5 \cdot 45$ & NS \\
\hline Total N:creatinine- $N$ & $13 \cdot 9$ & 0.96 & $14 \cdot 8$ & $1 \cdot 80$ & NS \\
\hline Urea-N : creatinine-N & $11 \cdot 5$ & $1 \cdot 14$ & $11 \cdot 7$ & $1 \cdot 56$ & NS \\
\hline \multicolumn{6}{|l|}{ Time-period 2} \\
\hline Total N & $224 \cdot 6$ & $6 \cdot 35$ & $229 \cdot 6$ & $11 \cdot 84$ & NS \\
\hline Urea-N & $172 \cdot 1$ & $4 \cdot 72$ & $192 \cdot 5$ & 13.05 & NS \\
\hline Total N:creatinine-N & $15 \cdot 1$ & $1 \cdot 40$ & $15 \cdot 9$ & 0.80 & NS \\
\hline Urea-N:creatinine-N & $11 \cdot 6$ & $1 \cdot 39$ & $13 \cdot 2$ & 0.52 & NS \\
\hline
\end{tabular}

NS, not significant.

$\dagger$ For details of diets and procedures, see Tables 1 and 4 and pp. $740-745$.

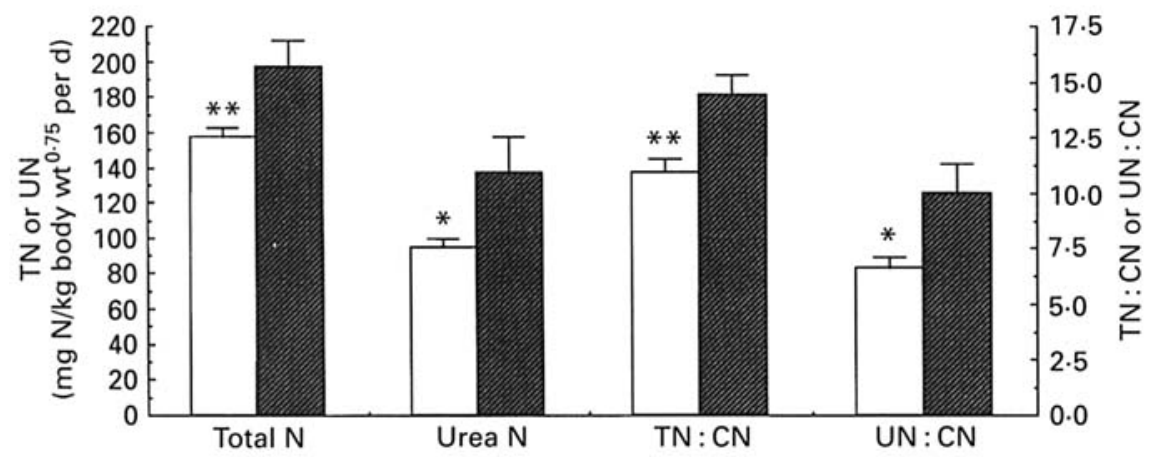

Fig. 2. Comparison of the mean daily urinary excretion of total $N(T N)$ and urea-N (UN), and the ratios between TN and the mean daily urinary creatinine-N (CN) excretion (TN:CN) and between UN and CN (UN:CN) in time-period 3 for catheterized piglets $(\square ; n 8)$ fed on a milk-formula diet balanced for all amino acids except cysteine $\left(\mathrm{S}+\right.$ diet) and unoperated piglets $\left(\mathrm{x}^{\mathrm{m}} ; n\right.$ ) fed on a diet $60 \%$ deficient in methionine and $40 \%$ deficient in cysteine $(S-$ diet). Values are means with their standard errors represented by vertical bars. Mean values for piglets fed on the $\mathrm{S}+$ diet were significantly different from those for piglets fed on the $\mathrm{S}-\operatorname{diet}:{ }^{*} P<0 \cdot 05,{ }^{* *} P$ $<0.01$.

unoperated piglets were given the $\mathrm{S}$ - diet and the excretion of urinary $\mathrm{N}$ metabolites by these piglets was significantly $(P<0.05)$ greater than that for the eight catheterized piglets which were given the $\mathrm{S}+\operatorname{diet}$ (Fig. 2).

The excretion of urinary $\mathrm{N}$ metabolites by piglets fed on the $\mathrm{L}$ - or $\mathrm{S}$ - diets in timeperiod 2 was significantly greater $(P<0.01)$ than that from the same pigs fed on the $\mathrm{L}+$ or $\mathrm{S}+$ diets in time-period 3 (Figs. 3 and 4 ). 


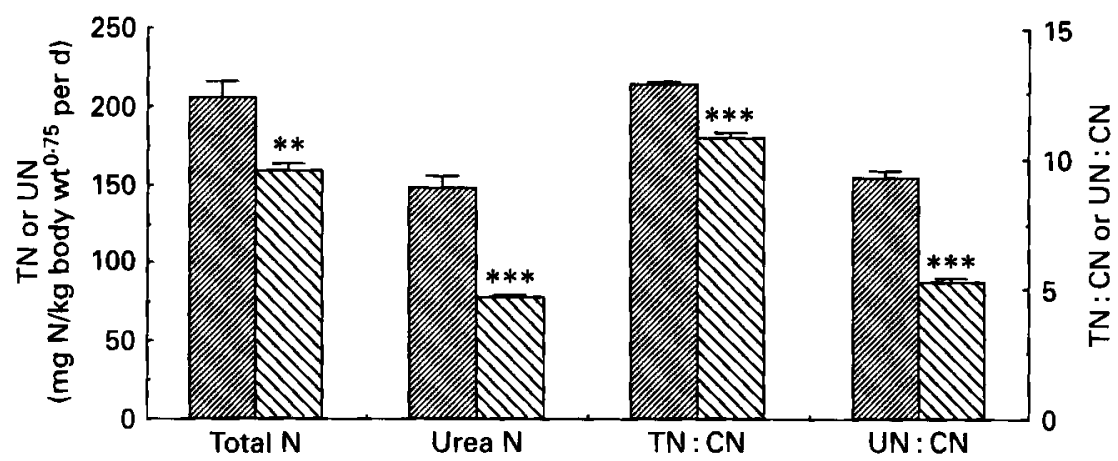

Fig. 3. Comparison of the mean daily urinary excretion of total $\mathbf{N}$ (TN) and urea-N (UN), and the ratios between TN and the mean daily urinary creatinine-N (CN) excretion (TN:CN) and between UN and $C N$ (UN:CN) for catheterized piglets $(n 6)$ fed on a milk-formula diet $40 \%$ deficient in lysine (河 ; L - diet) during time-period 2 and the same piglets fed on a milk-formula diet balanced for all amino acids $(\mathbb{Q} ; \mathrm{L}+$ diet) during time-period 3. Values are means with their standard errors represented by vertical bars. Mean values for piglets fed on the $\mathrm{L}$ - diet were significantly different from those when the same piglets were fed on the $\mathrm{L}+$ diet: **P $<0.01, * * * P<0.001$.

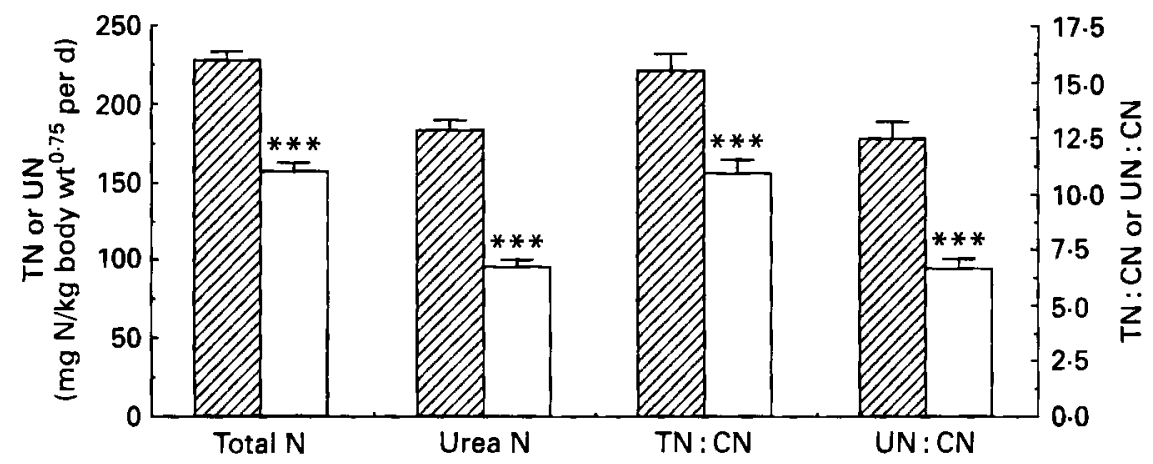

Fig. 4. Comparison of the mean daily urinary excretion of total nitrogen (TN) and urea-N (UN), and the ratios between TN and the mean daily urinary creatinine-N (CN) excretion (TN:CN) and between UN and $\mathrm{CN}$ (UN: $\mathrm{CN}$ ) for catheterized piglets $(n 8)$ fed on a milk-formula diet that was $60 \%$ deficient in methionine and $40 \%$ deficient in cysteine ( $\square ; S$ - diet) during time-period 2 and the same piglets fed on a milk-formula diet balanced for all amino acids except cysteine $(\square ; \mathbf{S}+$ diet) during time-period 3 . Values are means with their standard errors represented by vertical bars. Mean values for piglets fed on the $\mathrm{S}-$ diet were significantly different from those when the same piglets were fed on the $\mathrm{S}+$ diet: $* * * P<0.001$.

\section{DISCUSSION}

The present study was designed to determine whether lysine or methionine can be absorbed in nutritionally significant amounts from the proximal colon of the milk-formula-fed piglet. Piglets given diets deficient in a particular dietary essential amino acid are unable to utilize all the absorbed dietary amino acids for body protein deposition. Excess amino acids are catabolized and the $\mathrm{N}$ excreted in the urine. If the deficient amino acids are infused into the proximal large intestine and are absorbed in nutritionally significant amounts, the improvement in amino acid balance and subsequent increase in body protein deposition would be expected to lead to a marked decrease in the urinary excretion of $\mathrm{N}$-containing metabolites.

The piglets were fed on milk-formula diets balanced for all essential amino acids except lysine $\left(\mathrm{L}_{-}\right)$or methionine and cysteine $(\mathrm{S}-)$, and infused with amounts of amino acid 
consistent with the expected flow of the amino acid entering the large intestine of piglets given a completely balanced diet. The levels of amino acid infused into the proximal colon represented $13.3 \%$ and $12.3 \%$ of the lysine and methionine fed $/ \mathrm{kg}$ liveweight per $\mathrm{d}$ respectively. It was anticipated that at this level the infused amino acids, if absorbed, would have been sufficient to produce a response in the urinary $\mathrm{N}$ metabolite excretion. An increase in the amount of the deficient amino acid in the piglet's metabolic amino acid pool should have enabled the other amino acids to be utilized more efficiently, thus providing a sensitive assay. Surgical intervention and the presence of catheters in the caecum and proximal colon appeared to have no effect on urinary $\mathrm{N}$ metabolite excretion (Fig. 1).

It is important to note that the site for potential amino acid absorption was not clearly defined in the present study. Although the catheter was introduced into the caecum and the tip of the catheter placed well past the ileo-caecal junction, a possible back flow of amino acids into the terminal ileum could have occurred and resulted in the absorption of infused amino acids from the distal small intestine. The absence of $\mathrm{HA}$ in ileal contents following infusion of this amino acid into the large intestine indicated that back flow did not occur to any significant extent. Absorptive capacity may vary throughout the large intestine. Olszewski \& Buraczewski (1978) observed amino acid absorption in the caecum of growing pigs, while in other studies (James \& Smith, 1976) evidence was found of amino acid uptake by the mucosa from the proximal large intestine. It is possible that the infusate used in the present study did reflux into the caecum, though the main region for potential absorption would probably have been the proximal colon.

The use of ostomy plates and bags in the present study ensured that coprophagy did not occur, which would have led to difficulties in the interpretation of the metabolite excretion data. In addition, the use of ostomy bags ensured the collection of uncontaminated urine. While total collection of urine could not be assumed in the present study, with the possible loss of urinary $\mathrm{N}$ as ammonia before the urine was acidified, care was taken to minimize any urinary $\mathrm{N}$ loss. The overall mean for the individual piglet's coefficient of variation for daily urinary creatinine- $N$ excretion was $14.7 \%$. An average coefficient of variation of $7 \%$ for creatinine excretion was determined under conditions of complete urine collection from rats (Das \& Waterlow, 1974). Since the coefficient of variance observed in the present study was higher than would be expected based on random variation in creatinine excretion, urine collection may not have been complete. For the purposes of relative comparison, however, the urinary $\mathrm{N}$ metabolite excretion values and their ratios to creatinine determined in the present study were considered adequate.

The validity of this experiment also relied on the assumption that the milk-formula diets were sufficiently deficient to allow for a significant response in urinary $N$ metabolite excretion consequent upon possible absorption of the limiting amino acid. Given, from a comparison in time-period 2, that there appeared to be no significant effect of surgical intervention on the excretion of urinary $N$ metabolites (Fig. 1), in time-period 3 a comparison was made between the mean daily urinary $\mathrm{N}$ metabolite excretion rates of the catheterized piglets given the $S+$ diet, and that of the unoperated piglets given the $S-$ diet (Fig. 2). The mean daily urinary $\mathrm{N}$ metabolite excretion rates for the piglets given the $\mathrm{S}+$ diet were significantly lower than those for piglets given the $S$ - diet which indicates that the $S$ - diet was deficient in sulphur amino acids. A similar direct comparison with the Land $\mathrm{L}+$ diets was not made.

Further evidence that the $\mathrm{L}-$ and $\mathrm{S}$ - diets were suitably deficient is shown by comparison of the mean daily urinary $\mathrm{N}$ metabolite excretion rates for piglets given either the $\mathrm{L}-$ or $\mathrm{S}-$ diets during time-period 2 and the excretion rates for the same piglets given either the $\mathrm{L}+$ or $\mathrm{S}+$ diets during time-period 3 (Figs. 3 and 4). In time-periods 1 and 2 when the piglets were given the $\mathrm{L}-$ and $\mathrm{S}$ - diets, urinary $\mathrm{N}$ metabolite excretion showed 
a significant increase over time. However, in time-period 3 there was a significant reduction in mean daily urinary $\mathrm{N}$ metabolite excretion when the piglets received balanced diets compared with those in time-period 2 when they received deficient diets. Thus, the apparent increase in urinary $\mathbf{N}$ metabolite excretion over time was reversed and excretions were significantly reduced when balanced diets were fed to the piglets. It is concluded that during time-periods 1 and 2 the piglets were in a state of amino acid deficiency so that there would have been a significant decrease in urinary $\mathrm{N}$ metabolite excretion had infused amino acids been absorbed from the proximal colon.

The mean daily urinary $\mathrm{N}$ excretion rates for piglets given either diets $\mathrm{L}-$ and $\mathrm{S}-$ and infused with physiological saline or the deficient amino acids were similar, indicating that lysine and methionine were not absorbed in significant amounts from the proximal colon of the milk-formula-fed piglet.

Previous studies have shown that amino acids are not absorbed from the hindgut of growing pigs (Zebrowska, 1973, 1975, 1978; Just et al. 1981; Schmitz et al. 1991). In contrast to these studies, Olszewski \& Buraczewski (1978) and Niiyama et al. (1979) suggested that amino acids may be absorbed from the hindgut of growing pigs. Olszewski \& Buraczewski (1978) measured the disappearance of infused amino acids from an isolated pig caecum in situ. Microbiological degradation was limited by flushing the caecum with antibiotics. They concluded that as amino acids disappeared selectively from the caecal sac an active transport system must be present rather than absorption by simple diffusion. This is contradicted, however, by other studies and reviews stating that no active transport systems exist in the hindgut epithelium (Batt \& Schachter, 1969; Binder, 1970; Munck, 1981).

Niiyama et al. (1979) measured the absorption of microbial amino acids from the colon of growing pigs by determining the ${ }^{15} \mathrm{~N}$ concentration of free amino acids in colonic venous blood after infusion of ${ }^{15} \mathrm{~N}$-labelled micro-organisms into the caecum. Although ${ }^{15} \mathrm{~N}$-amino acids were located in the blood, ${ }^{15} \mathrm{~N}$-ammonia may have been absorbed and subsequently converted to amino acids within the body. Niiyama et al. (1979) concluded, however, that because of the difficulty in transferring $\mathrm{N}$ from ammonia to an amino acid group, ${ }^{15} \mathrm{~N}$ amino acids found in the venous blood supply of the colon were directly derived from the infused micro-organisms.

Olszewski \& Buraczewski (1978) and Niiyama et al. (1979) have shown that amino acids may be absorbed into the mucosa, serosa and possibly the blood supply of the caecal-colon region. They did not, however, measure any metabolic variables that would identify whether the amounts of amino acids absorbed were of nutritional significance.

While it appears that amino acids are not unlikely to be in the hindgut of growing animals, there is some evidence that amino acids may be absorbed from either the caecal or colonic epithelium in several species of young animal (Batt \& Schachter, 1969; James \& Smith, 1976; Heine et al. 1987).

In vitro studies using isolated segments of new-born and neonatal piglet proximal colon detected the movement of methionine into the epithelium (James \& Smith, 1976; Smith \& James, 1976; Jarvis et al. 1977). Sepulveda \& Smith (1979) identified two mechanisms for entry of neutral amino acids into the new-born piglet proximal colon using in vitro methodology. Although these studies demonstrated a definite movement of amino acids into the hindgut epithelial mucosa, there was no evidence that such capacity would occur in vivo. In addition, all the studies indicated diminishing absorptive capacity with age. James \& Smith (1976) noted that absorption was reduced considerably by $4 \mathrm{~d}$ and was almost undetectable by $10 \mathrm{~d}$ of age. This loss of activity has been attributed to a change in the epithelial cell structure of the hindgut soon after birth (Holdsworth \& Hastings-Wilson, 1967; Henin \& Smith, 1976; James \& Smith, 1976; Potter \& Lester, 1984). 
The uptake of amino acids into the colonic mucosa and serosa was not directly determined in the present work. However, it can be concluded that free lysine and methionine are not absorbed in nutritionally significant amounts from the proximal colon of the milk-formula-fed piglet (15-32 d old). Further research is needed to evaluate whether this is true for all amino acids, and to determine whether the caecal epithelium alone is capable of absorbing amino acids. The results of this, and other studies, support the use of an ileal digestibility assay with young milk-formula-fed piglets.

\section{The authors wish to thank the New Zealand Dairy Board for financial support.}

\section{REFERENCES}

Agricultural Research Council (1981). The Nutrient Requirements of Pigs. Slough: Commonwealth Agricultural Bureaux.

Association of Official Analytical Chemists (1980). Official Methods of Analysis, vol. 14. Washington DC: Association of Official Analytical Chemists.

Batt, E. R. and Schachter, D. (1969). Developmental pattern of some intestinal transport mechanisms in newborn rats and mice. American Journal of Physiology 216, 1064-1068.

Binder, H. J. (1970). Amino acid absorption in the mammalian colon. Biochimica et Biophysica Acta 219 , 503-506.

Brown, J. A. \& Cline, T. R. (1972a). Urea excretion in swine fed amino acid deficient diets. Journal of Animal Science 35, $211-212$.

Brown, J. A. \& Cline, T. R. (1972b). Urinary urea and amino acid requirements of swine. Journal of Animal Science 35, 1102.

Das, T. K. \& Waterlow, J. C. (1974). The rate of adaptation of urea cycle enzymes, aminotransferases and glutamic dehydrogenase to changes in dietary protein intake. British Journal of Nutrition 32, 353-373.

Heine, W., Wutzke, K., Richter, F. W. \& Plath, C. (1987). Evidence of colonic absorption of protein nitrogen in infants. Acta Paediatrica Scandinavica 76, 741-744.

Henin, S. \& Smith, M. W. (1976). Electrical properties of pig colonic mucosa measured during early post-natal development. Journal of Physiology 262, 169-187.

Holdsworth, C. D. \& Hastings-Wilson, T. (1967). Development of active sugar and amino acid transport in the yolk sac and intestine of the chicken. American Journal of Physiology 212, 233-240.

Hoover, W. H. \& Heitmann, R. N. (1975). Caecal nitrogen metabolism and amino acid absorption in the rabbit. Journal of Nutrition 105, 245-252.

James, P. S. \& Smith, M. W. (1976). Methionine transport by pig colonic mucosa measured during early postnatal development. Journal of Physiology 262, 151-168.

Jarvis, L. G., Morgan, G., Smith, M. W. \& Wooding, F. B. P. (1977). Cell replacement and changing transport function in the neonatal pig colon. Journal of Physiology 273, 717-729.

Jorgensen, H. \& Sauer, W. C. (1982). Amino acid availabilities in protein sources for swine. In The University of Alberta 61st Annual Feeders' Day Report, pp. 86-88. Edmonton, Alberta: University of Alberta Faculty of Extension.

Just, A. (1983). The role of the large intestine in the digestion of nutrients and amino acid utilisation in monogastrics. In Protein Metabolism and Nutrition. Proceedings of the IVth International Symposium, pp. 281-309 [R. Pion, M. Arnal and D. Bonin, editors]. Paris: Institut National De La Recherch Agronomique.

Just, A., Jorgensen, H. \& Fernandez, J. A. (1981). The digestive capacity of the caecum-colon and the value of the nitrogen absorbed from the hind-gut for protein synthesis in pigs. British Journal of Nutrition 46, $209-219$.

Larsen, K. (1972). Creatinine assay by a reaction-kinetic principal. Clinica Chimica Acta 41, 209.

Low, A. G. (1980). Nutrient absorption in pigs. Journal of the Science of Food and Agriculture 31, $1087-1130$.

McNeil, N. I. (1988). Nutritional implication of human and mammalian large intestinal function. World Review of Nutrition and Dietetics 56, 1-42.

Moughan, P. J., Pedraza, M., Smith, W. C., Williams, M. \& Wilson, M. (1990). An evaluation with piglets of bovine milk, hydrolysed bovine milk, and isolated soybean proteins included in infant milk formulas. 1 . Effect on organ development, digestive enzyme activities, and amino acid digestibility. Journal of Pediatric Gastroenterology and Nutrition 10, 385-394.

Moughan, P. J. \& Smith, W. C. (1982). Aspects of protein digestion and absorption in monogastrics with particular reference to dietary formulation. Proceedings of the Nutrition Society of New Zealand 7, 55-65.

Munck, B. G. (1981). Intestinal absorption of amino acids. In Physiology of the Gastrointestinal Tract, vol. II, pp. 1097-1122 [L. R. Johnson, editor]. New York: Raven Press.

Niiyama, M., Deguchi, E., Kagota, K. \& Namioka, S. (1979). Appearance of ${ }^{15} \mathrm{~N}$-labelled intestinal microbial amino acids in the venous blood of the pig colon. American Journal of Veterinary Research 40, 716-718. 
Olszewski, A. \& Buraczewski, S. (1978). Absorption of amino acids in isolated pig caecum in situ. Effect of concentration of enzymatic casein hydrolysate on absorption of amino acids. Acta Physiologica Polonica 29. 67-77.

Potter, G. D. \& Lester, R. (1984). The developing colon and nutrition. Journal of Pediatric Gastroenterology and Nutrition 3, 485-487.

Sauer, W. C. \& Ozimek, L. (1986). Digestibility of amino acids in swine: results and their practical application. A review. Livestock Production Science 15, 367-388.

Schmitz, M., Ahrens, F., Schön, J. \& Hagemeister, H. (1991). Amino acid absorption and its significance for protein supply. In Digestive Physiology in Pigs, pp. 85-87 [M. W. A. Verstegen, J. Huisman, and L. A. Den Hartog, editors]. Wageningen: Pudoc.

Sepulveda, F. V. \& Smith, M. W. (1979). Different mechanisms for neutral amino acid uptake by new-born pig colon. Joumal of Physiology 286, 479-490.

Smith, M. W. \& James, P. S. (1976). Amino acid transport by the helicoidal colon of the new-born pig. Biochimica et Biophysica Acta 419, 391-394.

Tiffany, T. O., Jansen, J. M., Burtis, C. A., Overton, J. B. \& Scott, C. D. (1972). Enzymatic kinetic rate and endpoint analyses of substrate by use of a GeMSAEC fast analyser. Clinical Chemistry 18, 829.

Zebrowska, T. (1973). Digestion and absorption of nitrogenous compounds in the large intestine of pigs. Roczniki Nauk Rolniczych. Series B 95, 85-90.

Zebrowska, T. (1975). The apparent digestibility of nitrogen and individual amino acids in the large intestine of pigs. Roczniki Nauk Rolniczych 97, 117-122.

Zebrowska, T. (1978). Apparent digestibility of nitrogen and amino acids and utilization of protein given orally or introduced into the large intestine of pigs. Roczniki Nauk Rolniczych. Series B 99, 99-104.

Zebrowska, T. (1982). Nitrogen digestion in the large intestine. In Physiologie Digestive Chez le Porc, pp. 225-236, [J. P. Laplace, T. Corring and A. Rerat, editors]. Paris: Institut National de La Recherche Agronomique. 